\title{
Discovering Voices: College Students and Middle Schoolers Explore Identities, Differences, and Connections through the Structure of a Poem
}

\author{
Alison Cook-Sather \\ Bryn Mawr College \\ U. S. A. \\ Anne Kenealy \\ Westinghouse College Prep \\ U. S. A. \\ Maurice Rippel \\ Haverford College \\ U. S. A. \\ Julia Beyer \\ Friends' Central School \\ U. S. A.
}

ABSTRACT: Co-authored by a college professor, a middle-school teacher, a college undergraduate, and a $7^{\text {th }}$ grader, this article focuses on college and middle-school students' experiences of discovering their own and others' voices. The discovery unfolds through composing and reflecting on poems in the form of Jacqueline Woodson's "it'll be scary sometimes," which focuses on the experience of being different. The students' dis-covering of voices deepens their own and their teachers' education and creates spaces, structures, and processes that affirm students' diverse histories and identities. Honoring differences and finding connections in these ways contribute to greater equity and inclusiveness.

KEYWORDS: difference, identities, diversity, equity, inclusiveness

Literature and Approach

Meeting at the Intersection

College Students Exploring Their Identities, Differences, and Connections Middle School Students Exploring Their Identities, Differences, and Connections Recommendations for Adapting this Assignment

Conclusion

References

Author Contact

Much separates middle school Language Arts classes from college-level Educational Studies courses, but there can also be surprising meeting places. In this praxis article, we tell the story of the creation and completion, at the intersection of Anne's and Alison's teaching worlds, of an assignment built around Jacqueline Woodson's (2016) poem "it'll be scary sometimes." To situate this story 
we summarize key arguments from literature on multicultural education, culturally relevant and sustaining pedagogy, and social justice education, and we explain our approach to telling this story. We then describe how the assignment came about and share the experiences and insights of Julia, Maurice, and other middleschool and college students who completed the assignment. Our goal is to illuminate how working with Woodson's poem contributed to college and middle school students discovering voices-Woodson's, her ancestors', students' own, their literal or spiritual ancestors', and one another's-and to Alison and Anne discovering voices of students that they might not otherwise have heard. We conclude with recommendations for how such a discovering of voices can deepen students' and teachers' education, affirm the diversity of students' histories and identities, and take steps toward greater equity and inclusiveness through both honoring differences and finding connections.

\section{Literature and Approach: Toward Culturally Relevant, Sustaining, and Inclusive Social Justice Pedagogy and Analysis}

Multicultural education is "a site of struggle for the power to define the purposes and processes of education in a diverse and unequal world" (Sleeter, 2018, p. 6). Such education requires that those who have been in charge "learn to listen to and take seriously those they have learned to dismiss" (Sleeter, 2018, p. 15). From our perspective, students are among those who have not been listened to and have been dismissed, and their diverse experiences and identities are too often excluded from what is studied in college courses and middle-school classes. Key arguments from culturally relevant, culturally sustaining, and inclusive pedagogy support the social justice approach we took to designing an assignment for a college course and a $7^{\text {th }}$-grade class.

Culturally relevant pedagogy recognizes and values a diversity of students (Colbert, 2010; Fasching-Varner \& Seriki, 2012; Pappamihiel \& Moreno, 2011), centers students' knowledge and experiences, builds deep relationships, and incorporates "content and activities that directly connect with students (Howard, 2003; Ladson-Billings, 2011; Lopez, 2011; Milner, 2011)" (Shannon-Baker, 2018, p. 57). Consistent with what Paris (2012) has called "culturally sustaining pedagogy," which values cultivating the cultural capital of students while also validating their diverse languages, cultures, and experiences as sites of knowledge production (Delgado-Bernal 2002), the assignment we discuss here creates structures and space for students to speak as and for themselves, in their own languages, and also in ways that feel educative and empowering to them. Such inclusive pedagogy, Obidah has argued, "allows intellectual and critical spaces to exist wherein students may make meaning and find power for themselves"' (as cited in Tuitt, 2003, p. 248).

To support such practices, Tatum (2015) called for creating "climates of engagement" in which students can succeed through affirming identity, building community, and cultivating leadership. Such climates strive to balance attention to 
integrated and individuated cultural frameworks (Chávez \& Longerbeam, 2016). The assignment we describe here strives to create such a climate and such a balance, and it "make[s] social justice activism within the course explicit to the students" (Lawyer, 2018, p. 97), thereby aiming to make social justice inherent in multicultural education (Cho, 2017).

The approach we take to describing how the assignment was developed and experienced is consistent with student voice work more broadly, which has shifted from conceptualizations of "students as a "data source"" toward "more active student-teacher partnerships" (Groundwater-Smith \& Mockler, 2015, p. 159; see also Cook-Sather, forthcoming, and Fielding, 2004). Students and teachers were partners in developing, completing, and sharing the results of the assignment. The voices included here, in addition to the authors', belong to a diversity of college and $7^{\text {th }}$-grade students, each of whom gave written permission (and, in the case of minors, written permission from their parents) to include their words and names in this discussion. Indeed, including those voices and names is integral to the social justice project of multicultural education, through which we "learn to listen to and take seriously those [we] have learned to dismiss" (Sleeter, 2018, p. 15).

\section{Meeting at the Intersection: The Advent of the Assignment}

The story begins in the $7^{\text {th }}$ grade Language Arts class Anne taught at Friends' Central School just outside of Philadelphia. Anne selected Jacqueline Woodson's (2016) Brown Girl Dreaming as one of the texts to assign to her $7^{\text {th }}$ grade students because its coming-of-age story with themes of family journeys and nostalgia for childhood has the potential to resonate with any middle school student. Brown Girl Dreaming is a memoir-in-verse set during the Civil Rights Movement, and the language of Woodson's poems is simple and accessible while avoiding any semblance of superficiality. The text asks readers to look closely at their understandings of identity, justice, and perspective as they experience the poetic speaker, Jacqueline, doing the same.

One fall night during the first year that Anne included Brown Girl Dreaming in her curriculum, Alison was reading the book aloud to her daughter, then a student in Anne's $7^{\text {th }}$ grade Language Arts class, and they came to the poem, "it'll be scary sometimes." Alison was in the midst of co-designing "Advocating Diversity in Higher Education," a course she planned to teach at Bryn Mawr College that spring, with Crystal Des-Ogugua, an undergraduate student at Bryn Mawr. Upon reading the poem, Alison immediately felt that the accessible and deeply powerful way Woodson portrayed the experience of the "moment when you walk into a room and / no one there is like you" would resonate for the students who would choose to take a course on advocating diversity in higher education, because of their own experiences or their commitment as allies.

The assignment Alison imagined would ask the students enrolled in "Advocating Diversity in Higher Education" to use the structure of Woodson's poem 
to tell the story of a "moment when you walk into a room and / no one there is like you" - the history behind the moment and the legacy of it. But, as a middle-aged White woman, Alison was worried that the assignment could be interpreted as a form of cultural appropriation, and she expressed that concern to Crystal, who is a Black woman. Crystal felt that the assignment would not constitute a form of cultural appropriation if it met two criteria. The first was that it be framed explicitly as not about equating people's experiences but rather about both honoring differences and looking for possible/potential points of connection. The second was that it be situated within the larger frame of the class as aiming to support participating in developing capacity to communicate, learn, and live across differences and non-intersections. A colleague of Alison's suggested an additional way to avoid that danger: to offer the option not to write the poem and to explain why, to ensure that there is critical dialogue around how students situate themselves in relation to the poem.

Guided by Crystal and her colleague, Alison framed the assignment this way:

- Read the poem, ideally aloud and ideally several times

- Then follow the instructions for writing your own poem

- As explained on the assignment, if you feel like you do not want to or cannot compare your 'only' experience to Woodson's poem, this can be what you write about. I hope you'll try to write the poem, but I want to offer an alternative if it just doesn't feel right to you.

- This is not about equating people's experiences; it's about both honoring differences and looking for points of connection.

The template for the assignment looked like this:

The goal of this assignment is both to honor the experience Woodson describes and to consider similar or different ways in which each person in this class and those from whom they descend, as family members or in other ways, might be/have been the only one. Below on the left is Jacqueline Woodson's poem. On the right is a template derived from the structure of Woodson's poem. Please fill in the blanks but feel free to be creative. So, the first line should be a person (relative, friend, etc. of yours) who was the only one in a particular situation. The second line should be a state of being and a place. The third line should be a time. The fourth and fifth lines should be something built (could be something literal, like a structure, or could be more metaphorical, like a dream) and what he/she/they did next. Lines 7-11 should be something he/she/they choseor had - to fight for (or against) and what happened as a result. Etc. 


\begin{tabular}{|c|c|}
\hline It'll be scary sometimes & It'll be scary sometimes \\
\hline $\begin{array}{l}\text { My great-great-grandfather on my father's side } \\
\text { was born free in Ohio, } \\
1832 .\end{array}$ & $\begin{array}{l}\text { My [ } \\
\text { was born [ }[-\ldots\end{array}$ \\
\hline $\begin{array}{l}\text { Built his home and farmed his land, } \\
\text { then dug for coal when the farming } \\
\text { wasn't enough. Fought hard } \\
\text { in the war. His name in stone now } \\
\text { on the Civil War Memorial: }\end{array}$ & $\begin{array}{l}\text { Built [ } \\
\text { then [ } \\
\text { wasn't enough. Fought hard }\end{array}$ \\
\hline $\begin{array}{l}\text { William J. Woodson } \\
\text { United States Colored Troops, } \\
\text { Union, Company B } 5^{\text {th }} \text { Regt. }\end{array}$ & L \\
\hline $\begin{array}{l}\text { A long time dead but living still } \\
\text { among the other soldiers } \\
\text { on that monument in Washington D.C. }\end{array}$ & $\begin{array}{l}\text { A long time [ }[] \text { but living still } \\
\text { among the other [ }\end{array}$ \\
\hline $\begin{array}{l}\text { His son was sent to Nelsonville } \\
\text { lived with an aunt }\end{array}$ & $\begin{array}{l}\text { His/Her/Their [__ }] \text { was sent to [ } \\
\text { lived with [ }\end{array}$ \\
\hline $\begin{array}{l}\text { William Woodson } \\
\text { the only brown boy in an all-white school. }\end{array}$ & the only [__ ] ] ] in an all-[ \\
\hline $\begin{array}{l}\text { You'll face this in your life someday, } \\
\text { my mother will tell us } \\
\text { over and over again. } \\
\text { A moment when you walk into a room and } \\
\text { no one there is like you. }\end{array}$ & $\begin{array}{l}\text { You'll face this in your life someday, } \\
\text { my [_] will tell [ } \\
\text { over and over again. } \\
\text { A moment when you walk into a room and } \\
\text { no one there is like you. }\end{array}$ \\
\hline $\begin{array}{l}\text { It'll be scary sometimes. } \\
\text { But think of William Woodson } \\
\text { And you'll be all right. }\end{array}$ & $\begin{array}{l}\text { It'll be scary sometimes. } \\
\text { But think of [ } \\
\text { And you'll be all right. }\end{array}$ \\
\hline
\end{tabular}

\section{College Students Exploring Their Identities, Differences, and Connections through the Structure of a Poem}

Explaining its origin in Anne's assignment of Brown Girl Dreaming and her own reading aloud of "it'll be scary sometimes" to her daughter, Alison presented this assignment to undergraduate students (typically ages 18-21) in "Advocating Diversity in Higher Education" three weeks into the semester. By this time, she and the 20 students enrolled in the course had worked hard to build a class community in which people's differences were valued and respected. Through various activities that focused on bringing in diverse voices from beyond the walls of the classroom (Cook-Sather, Des-Ogugua, \& Bahti, 2017), developing or deepening the capacity for radical listening (Torosyan \& Cook-Sather, 2015), and sharing the diversity of needs and goals students bring to the course (Cook-Sather \& DesOgugua, 2017), the classroom had become a space where differences and 
connections could coexist. Students knew that their experiences and background knowledge would be incorporated into assignments (Shannon-Baker, 2018) and that they would be asked to "make meaning and find power for themselves"” (Obidah cited in Tuitt, 2003, p. 248). As part of the co-creation of the course with students enrolled in it, Alison completed the assignment as well.

On the day the poems were due, the class started out by having a conversation about the experience of writing the poem or choosing not to write it. Then, those who wished to read their poems aloud had the option to do so. According to student feedback, regardless of whether they wrote the poem or reflected on why they chose not to write it, the act of engaging with the assignment and then both talking about the experience and listening to one another read the poems aloud prompted a deep look at who the students felt they were, what informed that feeling and identity, and how they thought about history, place, relationship, and action as a result. Furthermore, each student recognized the range of ways in which others could be marginalized, thereby addressing Lawyer's (2018) concern that if multicultural education courses are not grounded in social justice, "there is a great potential for marginalized students to perpetuate the marginalization of other marginalized groups" (p. 94).

In our class discussion of the experience of writing the poem, students identified the range of experiences they had. Some described feeling limited by the structure, as if the words were not the right ones for them, and so felt constrained in telling their stories. Others described feeling that the words they chose for the actual poem did not capture the complexity of the story they wanted to tell, but the process of thinking through the composition evoked the story strongly. Still others described feeling that the effort of attempting to write the poem pushed them to new insights about themselves and new recognition of and respect for family members. And, finally, others described feeling the act of writing the poems as analogous to the building of a literal monument: a way of making visible and honoring those that might otherwise be forgotten.

Those who wished to read their poems aloud formed a circle in the middle of the classroom. The rest of the students formed a circle around that circle so they could listen attentively to the readings. This read-around of poem after poem juxtaposed the choices students made and threw into relief the ways that the poem invited each voice to find its history. For instance, in the following three opening stanzas of the poems they wrote, a Korean student, a Mexican-American student, and an Indian student each powerfully evoked their histories:

My grandfather on my mother's side

was born in Hwang-Hae-Do, North Korea

1926.

Built his home and attended school, then enlisted in the army when school wasn't enough. 
My migrant mother

was born into a privileged household in Hidalgo, Mexico

1997.

Built a different life for herself alongside my father in East Los Angeles, California, then forgot all about their luxurious houses in Mexico in order to provide for a better future in the states

because their privileged backgrounds weren't enough to buy happiness.

My father and mother

were born in two different cultures in India,

1984.

Built a foundation for their marriage, then traveled to America, where culture wasn't enough.

Listening to the poems read aloud, students noted how different people in the same "structure"-both that of family and that of the poem-can have different experiences; how the "only" experience has aspects in common and yet can be radically different based on context and identity. The discussion was full of deep listening, of pauses, of feeling. Reflecting on the experience of reading and listening, Maurice captured in his reflective journal what many students said they felt:

When we read the poems in class, and talked about them with the people around us, the moment felt surreal. I think at first I was uncomfortable with the amount of silence surrounding this part of the discussion, but looking back, it made me think about the gravity of the moment.

This recognition of the importance of letting there be space and silence around people's spoken words is an integral part of the deepening of everyone's education and the affirmation of the diversity of students' experiences and identities. The reverential silence Maurice described reflects, in this case, students affirming identity and building community (Tatum, 2015).

After writing the poems and, in some cases, reading them aloud, students reflected on the experience. It is in this reflective space that many students unpacked the experience of writing their poems and dug deeper into the power of the assignment. Student reflections highlight the contrast between the particular space we co-created, a classroom in which students felt that they could share their 
own and their families' lived vulnerabilities, and the world beyond that space. Such contrasts prompted questions about how people understand space and time; what we carry forward from those who preceded us; how struggles are transferred, or not, across generations; who can speak for whom, and indeed, who can speak, period.

Looking back on the experience of writing and reading his poem, Maurice reflected on the various steps in the process of the assignment and the insights that process prompted for him:

I thought the writing of the poem would be the hardest part. I wanted to honor the person I chose the way Woodson did. In this stage of the process, I realized that everyone in my class was likely encountering the same difficulties as I was-choosing who to write about. We all have trailblazers of sorts who have paved the way for us, and that commonality connects us, despite the many differences we bring wherever we go. How do we decide which trailblazer to honor in the poem?

At first, I felt limited by the structure. The template Woodson's poem provides works well for those that can also trace their ancestry back several generations, but it didn't feel like my personal story, nor my trailblazers, could fit neatly. I wanted to achieve what Woodson achieved in her poem: I felt the need to reach back deep into my ancestry, yet I felt insecure that I couldn't. My personal lineage is complicated by not knowing my father or any of the blood relatives on his side, and being abandoned by my birth mother.

I chose to tap into what I did know: my family's strong lineage of strong women, from my grandmother Berniece, a product of the Great Depression, the Second World War and the Civil Rights Movement, who overcame racism and sexism to raise a family of six children, to her daughter, Lynn, my aunt, the woman I call mother, who pulled me into her family and raised me to be the man I am today. I ultimately chose my sister because she has overcome all challenges that have come her way-physical, and academic:

My aunt's daughter-my cousin, my sister

was born, premature, the size of a hand in Florida

1996

Built her strength up to be able to stand, then able to walk, then run, but it wasn't enough. Fought hard to do well in school when they said she couldn't to earn a diploma which read:

April Rose Harvey Graduate of Springfield Twp. High School Class of 2016

A long time being but living still among the other faces 
who walked by her, and looked the other way.

Her transcript was sent to MontCo

lived with liberation

April Rose

the only girl with a brace in an all-able-bodied school

You'll face this in your life someday,

my mom will tell me

over and over again.

A moment when you walk into a room and

no one there is like you.

It'll be scary sometimes. But think of April Rose

And you'll be all right.

The writing of the poem made me pause to think about why I am at Haverford College, and why I am involved in the work I do; it's because of my family. My mom emphasized that out of my siblings and me that none of us can leave any of us behind. When I think about my own identity as a Black man, and how my daily life in some ways is an act of resistance, I feel a heaviness, a weight, a burden. As Zora Neale Hurston states, "I feel most colored when I am thrown against a sharp white background" (Hurston, 1928) or in my case, at Haverford College. I can never understand the experiences of my mother, though, who has to endure racism and sexism as a Womxn of Color in the world of finance, or that of my sister, a Womxn of Color who also has to experience forms of ableism in her daily life. Yet, I realize the love of my family has been what has made the weight lightened, the burden lifted, and it is where I draw strength.

Contrary to my original thoughts, it was the reading of the poem that proved to be scary; it was having to be vulnerable, having to share a piece of myself. While I was the first student to share, having a professor like Alison share first, as well as the previous weeks I spent just getting to know my classmates, helped alleviate my jangling nerves. I realized as I was sharing, and then as others shared, that so much time, history, and sense of self was in the room. I also wondered to myself: How much do we do this? How often do we really get to hear where we all come from, and who pushed us thus far? I could not think of any moments in an academic setting out of the space our class co-created with Alison and Crystal. However, this needs to happen more.

Thinking about my experiences at Haverford College, and observing greater national discourse, I see a necessity for us to find ways of seeing past both our perceived and our actual differences. In finding a greater appreciation and understanding through our commonalities, and the sense of belonging 
we all desire, we can begin to actualize what an inclusive culture can look like.

Part of what an inclusive culture looks like is making space for all ways of being. As we mentioned, while most students chose to write the poem, some chose not to. A legitimate form of engaging the assignment, this choice accomplished the same goal of prompting students to recognize and honor voices-Woodson's, her ancestors', students' own, their literal or spiritual ancestors', one another's-and of critically analyzing how they are positioned in the world, how their identities intersect with the visible and invisible dimensions of diversity that define everyone. One student explained her choice not to write the poem:

I am a child of privilege. My family immigrated as invaders and land-owners, they moved to the west coast to follow prophets and the east to find jobs. I am not proud of it, but it's true. The only time l've ever been the only one of something in a room is with something invisible, like sexuality or mental illness. Those aren't less valid forms of difference or separation, by any means, but they are simultaneously easier to hide and harder to inherit. Unless I choose to tell them, no one knows. I have the wonderful privilege of not being notable as I enter a room. I do not represent a culture to strangers. My family has moved and changed and fled, but always as part of a pack. Because of this history and this privilege, I don't feel comfortable completing the poem part of this assignment. I have no comparable experience. l've often been scared, but I have never been alone in that fear. Therefore, I feel it would be disrespectful to pretend an understanding I do not have. I don't think I could manage it without reducing something that should not be reduced. This, to me, seems like a moment in which I need to focus on listening instead of thinking about what to say.

The diversity of honorable and respectful ways that students engaged this assignment is part of what contributes to its power. The assignment makes space for and values these differences and the importance of attending to them.

\section{Middle School Students Exploring Identities, Differences, and Connections through the Structure of a Poem}

Alison told Anne about the assignment that Woodson's book inspired, and Anne pondered how she could adapt it for her $7^{\text {th }}$ graders (typically ages 12-13). As middle schoolers, many of Anne's students are experiencing a developmental stage that has them very aware of the ways in which they are different from others. The experience that Woodson describes so eloquently in "it'll be scary sometimes"- that of feeling alone and isolated because of your identity-is one that many $7^{\text {th }}$ graders are discovering for the first time. Because, unlike Alison's college students, Anne's students were studying Brown Girl Dreaming, Anne thought the assignment might also aid her students' understanding of the experiences of the poetic speaker and author by observing overlaps and 
distinctions across their stories and Woodson's story. As a result, Anne did not offer students the option not to write the poem because she saw it as a useful assessment of student comprehension.

She did, however, provide an environment that, like Alison's class, strives to support a diversity of students. Friends' Central School is a Quaker school that encourages students to "let their lives speak" and promotes testimonies of equality and community. Within that framework, Anne both invited and affirmed a range of ways of being and engaging, holding her students to high standards of academic and personal integrity while validating who they are as learners and people. Perhaps for this constellation of reasons, Anne's students felt able to share their work with her at such a vulnerable phase of their development.

In reflecting on their writing process, some $7^{\text {th }}$ graders reported that this was the first time they had gathered information from their families on the hardships of their ancestors. One Jewish student learned more about a beloved greatgrandmother's survival of the Holocaust and pondered what it might feel like to be "the only one" even within one's own family:

My great-grandmother on my dad's side was born a Jew in Nazi Poland, 1922.

Built a family of five siblings and two parents, being the oldest child, then kept hope through tradition, when times were difficult and when there wasn't enough. Fought hard to save up money, but there was only enough to send one family member to America.

She was the one, great-grandma Harriet, Traveled by ship, survived the harsh winter All alone.

Many students of immigrants reflected on their culture's relationship to the United States, considering whether they are more or less accepted in "mainstream" American culture than their parents were when they immigrated. One AsianAmerican student wrote, "This assignment made me consider, What dictates your ability to belong in the U.S. ? The U.S. faces similar challenges today as it did when America was founded, and when my parents and grandparents came over in 1980." Another student, Krisangi, whose parents immigrated from India, wrote about her father's experience:

My dad

was born in India,

1971.

Built his life there, then thought it

wasn't enough. Fought hard

to come to America with only $\$ 1,100$ :

Namit Bhargava, 
A courageous man, Hoping to start a new life.

A long time Hindu but living still among the other Americans. Keeping his head held high.

His daughter was sent to school lived with her family

Namit Bhargava

the only immigrant in an all-native room.

Through learning, reflecting upon, and writing about her father's immigration story, this student felt that she was better able to integrate Woodson's ancestral story with her own world. Across differences of time and place, she observed a unity of experience that included fighting oppression. "Writing this assignment," she wrote, "made me think about how even though some people may look different or have a different story, in the end we all usually come together and unite as one to stand up for what we believe in."

While more 7th graders chose to write about a family member than about themselves, some students felt personally connected to Woodson's great-greatgrandfather's experience of isolation. One student, who was interrogating their gender identity at the time of writing the poem, has since come out to their teachers as genderqueer. Through the composition of their poem, this student considered how a feeling of aloneness, when understood as common to many, can mitigate a sense of isolation: "There are so many other people that feel alone, too, and so, in a strange way, we all have each other, because we understand each other. That is the root of all belonging, which I actually discovered while writing this: Understanding." The beginning of their poem reads as follows:

I, young and free, was born falsely.

2003

Building an idea of me,

Then watching it be ripped down, and realizing it

Wasn't enough. Fighting hard

To develop what could become

Something true out of a lie.

It concludes:

You'll face this every day of your life, not just someday.

My mind will tell me

Over and over again.

A moment when you walk into a room and

No one there is like you.

It'll be scary sometimes. But think of another

And you'll be alright. 
Julia, who wrote a poem about her Polish mother, reflected on her writing process as follows:

I once heard that Frank McCourt always told his students to "dig deep, find your own voice" (Sande Dimmitt, 1997) and I thought about this line when I reflected on the experience of writing this poem. Working on this poem made me dig deeper into my own identity and search for my own voice to accurately represent my ideas and feelings. Therefore, on the one hand, this assignment helped me find my own voice; I made many drafts, trying to capture the feelings and emotions my mom had described. It also let me hear my mom's and dad's side of my family's voices. When I was brainstorming, I considered and learned several surprising stories from both my Polish and American sides. While doing that, I realized that all these different stories make up who I am. They are a part of my own identity. Their voices were made known to me through my mom and I uncovered a history of struggles, perseverance, and challenges that I had never known about before. These different voices of different generations opened my eyes to a recurring theme in my family's history: the stories of struggle and always being "the other," whether in Europe or the United States.

Creating this poem made me also reflect on what it means to be of a different culture or identity than everyone else, which in my case is being Polish. When I was younger, I often disliked that I was different than everybody else and often wanted to cover up my Polish identity. As I have grown older, I have realized that being different may be a challenge, but it is also there to make you stronger. I discovered that it is really a gift to be different! Writing such a poem also brought my mom and me together as we discussed our experiences. When writing and sharing my poem, I also felt a sense of pride that I could represent my culture and history through writing something I enjoy.

However, writing the poem also made me feel a little uncomfortable. I learned how incredibly hard it was for my mom to be one of the only Europeans in Japan, and I realized that, in comparison to what my mom had to go through, my life has been easy and privileged. I guess that's what happens when you dig deeper...

The whole poem, for me at least, focused on not having a sense of belonging and comfort. It dawned on me that people often think that they don't belong while others, who surround them, have the same feeling. My mom described being completely alone for a long time, with no group to identify with. She told me that when she finally realized that everyone in her group of students was just as "different" as her, she found it easier to make friends and have that coveted sense of belonging. I thought how paradoxical it is that people unite and connect when they embrace their differences and celebrate them. It occurred to me that especially in this hard time of being a teenager and in the troubled world we live in, we care so much about belonging to a group. Instead of trying so desperately to fit in, we should welcome each other's differences and it will connect us. 


\section{Recommendations for Adapting This Assignment}

We have written this article such that readers can follow our process for developing the "it'll be scary sometimes" assignment. Here we reiterate key moments, commitments, and actions as recommendations we have for teachers at all levels.

First, always be open to texts like Woodson's "it'll be scary sometimes" that convey a common phenomenon that is, at the same time, experienced differently by everyone, and integrate such texts into the curriculum. Such an approach contributes to centering students' knowledge and experiences, building deep relationships, and incorporating "content and activities that directly connect with students (Howard, 2003; Ladson-Billings, 2011; Lopez, 2011; Milner, 2011)" (Shannon-Baker, 2018, p. 57).

Second, when inviting students to link the experience represented in texts with their own experiences, frame those invitations explicitly as not about equating people's experiences but rather as about both honoring differences and looking for possible/potential points of connection. In addition, offer the option not to engage in the assignment but, instead, to offer a critical analysis of why not.

Finally, create spaces within class sessions for students to share their experiences and voices and to listen respectfully to one another, regardless of whether or not they share their own voices. As Lawyer (2018) argued in the recommendations she offered for revisioning praxis in multicultural education, "Create spaces that protect the autonomy of the marginalized students, allowing them to choose to educate their peers or remain in the background" (p. 97).

\section{Conclusion: Discovering Voices}

Woodson's poem dis-covers to students the lived experience of her mother, her great-great-grandfather, and herself and captures in a powerful poem an experience that so many Black people have had in the United States. The specificity and the capacity of the poem, the reassurance of survival over time and in each moment, make space both to tell Woodson's family story in a clear and powerful way and to invite the link to other stories of entering spaces where no one there is like you.

Working with Woodson's poem and their own, Alison's and Anne's students thought deeply about what it means to be and belong, to be linked with others and to be alone. They heard the individual details, the differences across their stories, also made similar by the structure of the poem, and perhaps some quality of human experience that they have in common across different particulars of being the only one in a space. As Maurice reflected: "We're all trying to find our place, our voice, in what can often be scary circumstances." Sanchez's (2017) reflection on her 
journey as a writer speaks to the hope for inclusiveness embedded in such a search: "The beautiful thing about your history and herstory is that you find other histories and herstories that are hidden" (p. B1).

Through this assignment, students learned how they themselves and how others experienced time, space, relationship, and fear. Important to all the students was the opportunity, as Maurice and Julia described, to sit with one another, listen to each other's stories, recognize the differences and similarities, and honor all of these. Everyone gained particular insights, and everyone had a shared, although not the same, experience of Solomon's (2012) claim, which Julia also discovered, that "difference unites us."

We do not in any way mean this assignment or this analysis of it to collapse differences among people, to equate different lived experiences, or to erase differences. Instead, we hope that by inviting and juxtaposing the differences among us, by structuring spaces within which students and teachers can find and forge our voices, we can learn from our differences, discovering the ways that difference unites us while preserving and honoring what makes us different. This is, we believe, a powerful way to move toward greater equity and inclusiveness.

\section{References}

Chávez, A. F, \& Longerbeam, S. D. (2016). Teaching across cultural strengths: A guide to balancing integrated and individuated cultural frameworks in college teaching. Sterling, VA: Stylus.

Cho, H. (2017). Navigating the meanings of social justice, teaching for social justice, and multicultural education. International Journal of Multicultural Education, 19(2), 1-19

Colbert, P. J. (2010). Developing a culturally responsive classroom collaborative of faculty, students, and institution. Journal of College Teaching \& Learning 7(11), 15-24.

Cook-Sather, A. (forthcoming). Tracing the evolution of student voice in educational research. In R. Bourke \& J. Loveridge (Eds.), Radical collegiality through student voice. Singapore: Springer Publishers.

Cook-Sather, A., \& Des-Ogugua, C. (2017, February). Advocating diversity: Cocreating structures for listening, learning, and taking action. Presentation at Lafayette College. Easton, PA.

Cook-Sather, A., Des-Ogugua, C., \& Bahti, M. (2018). Articulating identities and analyzing belonging: A multistep intervention that affirms and informs a diversity of students. Teaching in Higher Education, 23(3), 374-389.

Delgado-Bernal, D. (2002). Critical race theory, Latino critical theory, and critical raced-gendered epistemologies: Recognizing students of color as holders and creators of knowledge. Qualitative Inquiry 8(1), 105-126. 
Fasching-Varner, K. J., \& Seriki, V. D. (2012). Moving beyond seeing with our eyes wide shut. A response to "there is no culturally responsive teaching spoken here." Democracy \& Education 20(1). Retrieved from https://democracy educationjournal.org/home/vol20/iss $1 / 5 /$

Fielding, M. (2004). "New wave" student voice and the renewal of civic society. London Review of Education, 2(3), 197- 217.

Groundwater-Smith, S., \& Mockler, N. (2015). From data source to coresearchers? Tracing the shift from 'student voice' to student-teacher partnerships in educational action research. Educational Action Research 24(2), 159-176. https://doi.org/10.1080/09650792.2015.1053507

Howard, T. C. (2003). Culturally relevant pedagogy: Ingredients for critical teacher reflection. Theory into Practice, 42(3), 195-202.

Hurston, Z. N. (1928). How it feels to be colored me. Retrieved from https://www.cengage.com/custom/static_content/OLC/s76656_76218lf/hur ston.pdf

Ladson-Billings, G. (2011). "Yes, but how do we do it?": Practicing culturally relevant pedagogy. In J. G. Landsman \& C. W. Lewis (Eds.), White teachers /diverse classrooms: Creating inclusive schools, building on students' diversity, and providing true educational equity (pp. 33-46). Sterling, VA: Stylus Publishing.

Lawyer, G. (2018). The dangers of separating social justice from multicultural education: Applications in higher education. International Journal of Multicultural Education, 20(1), 86-101.

Lopez, A. E. (2011). Culturally relevant pedagogy and critical literacy in diverse English classrooms: A case study of a secondary English teacher's activism and agency. English Teaching: Practice and Critique, 10(4), 75-93.

Milner, H. R. (2011). But good intentions are not enough: Doing what's necessary to teach for diversity. In J. G. Landsman \& C. W. Lewis (Eds.), White teachers / diverse classrooms: Creating inclusive schools, building on students' diversity, and providing true educational equity (pp. 56-74). Sterling, VA: Stylus Publishing.

Pappamihiel, N. E., \& Moreno, M. (2011). Retaining Latino students: Culturally responsive instruction in colleges and universities. Journal of Hispanic Higher Education 10(4): 331-344. Retrieved from http://dx.doi/10.1177/ 1538192711410602

Paris, D. (2012). Culturally sustaining pedagogy: A needed change in stance, terminology, and practice. Educational Researcher 41(3): 93-97. doi:10.3102/0013189X12441244

Sanchez, S. (2017, February 26). A father comes to understand daughter's truths. Black history untold: Joy. The Philadelphia Inquirer, p. B1. 
Sande Dimmitt, B. (1997, November). The inspiring story of how Frank McCourt won a Pulitzer. Reader's Digest. Retrieved from https://www.rd.com/truestories/inspiring/frank-mccourt-pulitzer/

Shannon-Baker, P. (2018). A multicultural education praxis: Integrating past and present, living theories, and practice. International Journal of Multicultural Education, 20, 1, 48-66.

Sleeter, C. (2018). Multicultural education past, present, and future: Struggles for dialog and power-sharing. International Journal of Multicultural Education, 20, 1, 1-16.

Solomon, A. (2012). Far from the tree: Parents, children, and the search for identity. New York, NY: Scribner.

Tatum, B. D. (2015). "Can we talk about race? A conversation with Beverly Daniel Tatum." Keynote Address at the annual meeting of the Professional and Organizational Development Network. November 4-8, San Francisco, California, USA.

Torosyan, R., \& Cook-Sather, A. (2015). Revisiting 'active listening': Paradoxes and practices that prompt critical reflection. Conference of the Professional and Organizational Development Network in Higher Education. November 4-8, San Francisco, California, USA

Tuitt, F. (2003). Afterword: Realizing a more inclusive pedagogy. In A. Howell \& F. Tuitt (Eds.), Race and higher education: Rethinking pedagogy in diverse college classrooms (pp. 243-268). Cambridge, MA: Harvard Educational Review.

Woodson, J. (2016). Brown girl dreaming. New York, NY: Penguin Random House Books.

\section{Author Contact}

Alison Cook-Sather: acooksat@brynmawr.edu

Education Program, Bryn Mawr College 101 N. Merion Ave., Bryn Mawr, PA, 19010, U. S. A.

Anne Kenealy: alkenealy@gmail.com

Westinghouse College Prep, 3223 W. Franklin Blvd. Chicago, IL 60624, U. S. A.

Maurice Rippel: mrippel@haverford.edu

Haverford College, 370 Lancaster Ave, Haverford, PA 19041, U. S. A.

U.S. A.

Julia Beyer: jbeyer@friendscentral.org

Friends' Central School, 1101 City Ave, Wynnewood, PA 19096, U. S. A. 